\title{
Combining Physical Education and unstructured practice during school recess to improve the students' decision-making and execution Combinando las clases de Educación Física con práctica no estructurada durante los recreos para aumentar la toma de decisiones y la ejecución de los alumnos \\ *Alba Práxedes, **Rafael González, ***Fernando del Villar, ***Alexander Gil-Arias \\ *U niversity of N ebrija (España), ${ }^{* *}$ U niversity of Extremadura (España), ${ }^{* * *}$ Rey Juan Carlos U niversity (España)
}

\begin{abstract}
The purpose of thisstudy wasto analyze the effect of aunit of basketball based onTeaching Gamesfor U nderstanding model combined with a program of unstructured practice based on small-sided games (experimental group), in comparison to the only application of the unit (control group), on the decision-making and execution in Physical Education students. Participants were 31 students with ages between 12 and 14. The intervention was conducted over four weeks, developing eight PE lessons and eight school recess to unstructured practice. The decision-making and the execution of the pass action were measured by systematic observation, using the Game Performance EvaluationTool instrument. Results showed in the experimental group, significantly higher values in post-test with respect to pre-test, in both variables (decison-making, $p=$ .001 ; execution, $p=.024)$. Regarding to the control group, these differences were found only in the decision-making ( $p=$ .021). Findings demonstrated that the joined application of a unit with unstructured practise is more effective to improve decision-making and skill execution that if students areexpose only in the Physical Education lessons. Therefore, we recommend teachers promote opportunities to students to have experiences in school recess.
\end{abstract}

Key words: Unstructured Practice, school recess, decision-making, execution, TGfU, basketball.

Resumen: El propósito de este estudio fue analizar el efecto de una U nidad Didáctica de baloncesto basada en el modelo Enseñanza de los Juegos a través de la Comprensión, combinada con un programa de práctica no estructurada basado en juegos modificados (grupo experimental), en comparación con la aplicación únicamente de la U nidad Didáctica (grupo control), en la toma de decisiones y la ejecución en al umnos de Educación Física. Participaron 31 alumnos con edades entre 12 y 14 años. La intervención se realizó durante cuatro semanas, desarrollándose ocho clases de Educación Física y ocho recreos para la práctica no estructurada. La toma de decisiones y la ejecución fueron medidas a través de observación sistemática, usando el Instrumento de Evaluación del Rendimiento en el Juego. Los resultados mostraron en el grupo experimental, val ores significativamente más al tos en la evaluación final con respecto a la inicial, en ambas variables (toma de decisiones, $p=.001$; ejecución, $p=.024)$. . Con respecto al grupo control, estas diferencias se encontraron solo en latomade decisiones $(p=.021)$. Los resultados demostraron que la aplicación conjunta de una Unidad Didáctica con práctica no estructurada es más efectiva para mejorar tanto la toma de decisiones como la ejecución de las habilidades, en vez de exponer a los al umnos solo a las clases de Educación Física. Por tanto, se recomienda que los profesores promuevan oportunidades de práctica en los recreos para los alumnos.

Palabras clave: Práctica no estructurada, recreos, toma de decisiones, ejecución, TGfU, bal oncesto.

\section{Introduction}

The greater the amount of time in which children have high-quality experiences in sport practice is, the greater the skill acquisition they achieve will be (A raújo $\&$ Davids, 2011; Phillips, Davids, Renshaw \& Portus, 2010). Several authorshave been proposed that the skills acquisition could be developed whitin two practices (Coutinho, Mesquita, Davids, Fonseca \& Côté, 2016):

Fecha recepción: 23-09-20. Fecha de aceptación: 15-01-21

PreferenciasAlba Práxedes

apraxedes@nebrija.es micro-structure or structured practice (organised, teacher-led practice or also known as deliberated practice) and macro-structure or unstructured practice (non-organized, peer-led sporting play or also known as deliberated play). In other words, structured practice means that each learning activity may be carefully monitored, with a focus on immediate correction (e.g. within Physical Education, PE; Côté, Baker \&Abernethy, 2003), while unstructured practice represents funoriented learning activity without supervision (e.g. school recess; Côté, Baker \& Abernethy, 2007).

Regarding the structured practice, an important challenge for physical educators is to design effective 
learning tasks in preparation for the physical (i.e. the ability to perform skills in open settings), cognitive (i.e. the ability to use tactics and reflect on how to improve personal/ team performance), social (i.e. positive interactions with classmates) and affective (i.e. satiffaction and enjoyment being physically active) (Kirk, 2013). In team sports, where there is a prevalence of open skills, there is constant uncertainty in the game environment where the athlete develops the cognitive process of decision-making (García-González, M oreno, Gil-Arias, Moreno \& Del Villar, 2014), although the sport expertise level also depends on the skills execution (Práxedes, Moreno, Sevil, García-González \& Del Villar, 2016a; Lex, Essing, Knoblauch \& Schack, 2015).

Thus, within this structured practice and to improve the decision-making and execution skill, the Teaching Games for U nderstanding (TGFU) model, has received in the last decade, much support from practitioners and the research community alike, analyzing how this pedagogical approach can influence on different learning outcomes such as game performance (Harvey, Cushion, Wegis \& Massa-Gonzalez, 2010; M orales-Belando \& Arias-Estero, 2017), physical literacy (M andigo, Lodewyk \&Tredway, 2019), psycho-social variables (Harvey, GilArias, Smith \& Smith, 2017; Ú beda-Colomer, M onforte \& Devís Devís, 2016). Through game-centered approaches (GCAs), such as TGfU, students learn the tactical aspects of the game by playing modified/ conditioned versions of the game to develop game appreciation and tactical awareness (Harvey $\&$ Jarrett, 2014). In this sense, Bunker andThorpe (1982) suggested that modified and simplified versions of games could be used to teach the main tactics of the sport, and ther efore this pedagogical model requires the physical PE teacher to consider the students and to suit the game form to learners' developmental level (Harvey \& Jarrett, 2014). This facilitates the development of game play strategy and tactical decision-making related to both the on-and off-the-ball concepts required for effective game play (Turner \& Martinek, 1999). M oreover, and although the cognitive domain is prioritized (Metzler, 2011; Morales-Belando \& Arias-Estero, 2019), technical skills are simultaneously developed alongside tactics in contextualized situations (Small Sided Games; SSG) using the pedagogical principles of modification representation, modification exaggeration, and tactical complexity (Tan, Chow \& Davids, 2012). Also, questioning is applied to understand the game through tactical knowledge (Gréhaigne, Richard \& Griffin, 2005).

In this sense, SSG (commonly used modified games that take place in tight spaces, involving small numbers of players and with modified rules of the game) have been proposed to be an effective methodological tool to the skills acquisition such as decision-making (Davids, Araújo, Correia \&Vilar, 2013; H arvey \& Jarrett, 2014); Práxedes, et al., 2016a). These games, with active defenders presence, facilitate transfer of actions, perception and cognitions of athletes from training simulations to performance environments. Practising passing with a teammate, shooting in the absence of a defender or dribbling around cones, are all basketball activities with reduced levels of specifying information needed to regulate functional behavioursin real contexts (González-Espinosa, Feu, García-Rubio, Antúnez \& García-Santos, 2017; Práxedes, DelVillar, M oreno, GilArias \& Davids, 2019). To achieve learners make intelligent decisions based on their own, teammates' and opponent' action capabilities, these practices should be more dynamic (e.g. 2 vs. 1 with the objective to shoot to the basket with the lowest level of opposition) (Fajen, Riley \& Turvey, 2009). 0 n the other hand, when the TGfU model is applied, it is necessary to highlight the use of questioning as a cognitive tool that permits focusing attention on specific technical-tactical aspects by means of questions that the teacher asks the students (Vickers, 2007). In this regard,W ebb and Pearson (2008) indicate the usefulness of applying questioning to favour cognitive development and thus create a critical and reflexive attitude in students (Gréhaigne, et al., 2005), consequently improving the decision-making (GarcíaGonzález, et al., 2014) and the execution (Gil-Arias \& del Villar, 2014).

Regarding the unstructured practice, this is less organized. In those activities there are not a coach, but which emerge from the interactions of individuals who organise their own activities and games for the purposes of learning (Davids, Güllich, Shuttleworth, \& Araújo, 2016). Thus, these activities allow them to explore their independence and enhance their organization and leadership skills (Côté et al., 2007; Côté \& Erickson, 2015; Côté, Erickson, \& Abernethy 2013), promoting the formation of smart and creative players (Côté et al., 2007, Côté et al., 2013). Also, the absence of an adult, and consequently, the absence of a feedback, it contributes to enhance the level of autonomy for the children to perceive and solve problems that emerge in the game context (M achado, Bar reira, Galatti, Chow, Garganta \& Scaglia, 2018). In contrast to the original definition of deliberate play (Côté, et al., 2003, 2007), unstructured practice may also include spontaneous fun 
activities but with the goal of improving skills or performance (e.g. students playing handball in the school recces to improve the skills that they are learning in PE lessons) (Côté, et al., 2013). In this regard, unstructured play, which it can be developed in play environments like the school recess, has been related with the development of sport expertise(Ford \&W illiams, 2012). Nevertheless, little attention has been given to these practices (Coutinho, et al. , 2016; Forsman, et al., 2016). On the contrary, in the scientific literature, we found systematic reviews have suggested that school recess could makeameaningful contribution to physical activity of children and adolescents (Ridgers, et al., 2012; Parrish, O kely, Stanley \& Ridgers, 2013) and it is the most natural environment that children can find in the school, enjoying the freedom of organizing, establishing or modifying game rules and putting into practice different attitudes (Rodríguez-Fernández, Pereira, Pereira, \& Condessa, 2019).

Although it is clear that structured and unstructured play and practice activities are not completely divergent, there is a need for more research to understand how the benefits of unstructured practice and play can be captured in principles for formalised development programmes, which are not directly conceptualized, planned and over-seen by coaches and teachers (Coutinho et al. , 2016; Forsman et al. , 2016). Specifically, in the scientist literature, there are no research that have sought to investigate the effects of intervention programs that combine the structured practice and the unstructured practice on the decision-making and execution variables. Therefore, the main objective of this study was to analyze the effect of a unit of basketbaII (structured practice) based on the TGfU model (developed in PE lessons) combined with a program based on unstructured practice (developed in school recess), in comparison to the only application of the unit, on the decision-making and execution of the pass action in PE students.

\section{Method}

\section{Design and participants}

A purposive sampling method was used to recruit participants for this study (Creswell, 2014). Participants were 31 students $\left(M_{\text {age }}=12.39, S_{\text {age }}=.57\right)$, who were in their first year of secondary school and were members of two PE classes from one south-west Spanish public school. Studentshad not received formal basketball unit previously however, all participants had previous experience in other team sports (e.g. handball), which they were taught throughTGfU. 21 students from one class (identified such as experimental group) experienced aTGfU basketball unit combined with a program based on unstructured practice $\left(M_{\text {age }}=12.23\right.$, $S D_{\text {age }}=.436 ; n=9$ female), while 10 students from another class (identified such as control group) experienced only theTGfU basketball unit $\left(M_{\text {age }}=12.9\right.$, $\mathrm{SD}_{\text {age }}=.567, \mathrm{n}=3$ female), within a pre-test/ post-test quasi-experimental design. Students who didn't participated in two or more lessonsfrom the unir, didn't considered them as participants to this study (in total, 3 students from the experimental group and 8 students from de control group).

The teacher of both classes was a 25-year-old male who had two years of experience teaching PE. The teacher had not prior experience using TGfU. Consequently, he completed a training course in this pedagogical model, including the use of SSGs and questioning.

The research project was fully approved by theEthics Research Committee of the U niversity of Extremadura (Spain). The participantsand their parentswereinformed of the study and an informed written consent was obtained from the parents/ guardians. Participants were treated in agreement with the ethical guidelines of the American Psychological Association with respect to participant assent, parent/guardian consent, confidentiality and anonymity.

\section{Intervention}

Intervention program based on structured practice (TGFU model). This program was conducted, in both groups, in a unit of eight lessons (four weeks). Each lesson had a length of 55 minutes. Learning tasks were modified to consider the students and to suit the game form to learners' developmental level using the pedagogical principles of TGfU (i.e. representation, exaggeration, and tactical complexity). For example, modification representation (i.e. smaller formats such as 2 vs. 2 and 3 vs. 3) was used to increase the students' game involvement. Modification exaggeration was used by PE teacher to change/ modify game rules to emphasize specific tactical learning objectives (e.g. a maintaining possession game where the baskets were removed emphasized the use of different types of passes to move the ball between team members). And finally, taskswere presented in progressive 'layers' (i.e. numerical superiority in attack such as 2 vs. 1 and 3 vs. 2) so that tactical complexity was increased based on the tactical 
skill development of the students, by providing a greater time to make decisions and make it easier (Sampaio, Lago, Gonçalves, Maçãs \& Leite, 2014). Through this teaching approach, gameteaching promotes the learning of tactics and strategies of game play in tandem with technique development. Also, modified games allow to design tasks authentic and connected to the sport form (Kirk \& M cPhail, 2002). The objectives for the sessions were focused on the offensive skills, in which an integration of technical and tactical aspects was always sought, are displayed in Table 1.

\begin{tabular}{|c|c|c|}
\hline $\begin{array}{l}\text { Lesson } \\
\text { number }\end{array}$ & Lessons contents & Small-sided games \\
\hline 1 & Pass and reception & $\begin{array}{l}\text { Keep the ball possession: } 4 \text { vs. } 2 \\
\text { Progression towards the opposite field: } \\
2 \text { vs. } 1 \text { and } 3 \text { vs. } 2\end{array}$ \\
\hline 2 & $\begin{array}{l}\text { Pass and mobility to create } \\
\text { lines of pass }\end{array}$ & $\begin{array}{l}\text { Keep the ball possession: } 4 \text { vs. } 3 \\
\text { Progression towards the opposite field and shooting: } \\
2 \text { vs. } 1 \text { and } 3 \text { vs. } 2\end{array}$ \\
\hline 3 & Space (width in attack) & $\begin{array}{l}\text { Keep the ball possession: } 3 \text { vs. } 3 \\
\text { Progression towards the opposite field and shooting: } \\
3 \text { vs. } 2 \text { and } 4 \text { vs. } 3\end{array}$ \\
\hline 4 & $\begin{array}{l}\text { Penetration (progress to the } \\
\text { basket) }\end{array}$ & $\begin{array}{c}\text { Keep the ball possession: } 4 \text { vs. } 4 \\
\text { Progression towards the opposite field: } 4 \text { vs. } 3 \\
\text { Representation of a real match: } 3 \text { vs. } 3 \text { + wildcard }\end{array}$ \\
\hline 5 & $\begin{array}{l}\text { Creation and occupation of } \\
\text { free spaces }\end{array}$ & $\begin{array}{c}\text { Keep the ball possession: } 4 \text { vs. } 4 \\
\text { Progression towards the opposite field: } 4 \text { vs. } 3 \\
\text { Representation of a real match: } 3 \text { vs. } 3 \text { + wildcard }\end{array}$ \\
\hline 6 & $\begin{array}{l}\text { Creation of lines of passes II } \\
\text { Counter attack }\end{array}$ & $\begin{array}{l}\text { Keep the ball possession: } 4 \text { vs. } 4 \\
\text { Progression towards the opposite field: } 4 \text { vs. } 3 \\
\text { Representation of a real match: } 4 \text { vs. } 4 \text { + wildcard }\end{array}$ \\
\hline 7 & $\begin{array}{l}\text { Creation and occupation of } \\
\text { free spaces II }\end{array}$ & $\begin{array}{l}\text { Keep the ball possession: } 4 \text { vs. } 4 \\
\text { Progression towards the opposite field: } 4 \text { vs. } 4 \\
\text { Representation of a real match: } 4 \text { vs. } 4\end{array}$ \\
\hline 8 & $\begin{array}{l}\text { Space (with in attack) II } \\
\text { Penetration (progress to the } \\
\text { basket) II }\end{array}$ & $\begin{array}{l}\text { Keep the ball possession: } 5 \text { vs. } 5 \\
\text { Progression towards the opposite field: } 5 \text { vs. } 5 \\
\text { Representation of a real match: } 5 \text { vs. } 5\end{array}$ \\
\hline
\end{tabular}

In each lesson, three tasks of 15 minutes each one, and based on SSG s, were conducted. These were designed to be similar to the reality of the game and each referred to a offensive game principle (Bayer, 1992; Mitchell, 0 slin \& Griffin, 2006): (i) to keep the ball possession without the objective of progression towards the goal; (ii) to progress towards the goal beating a defence line and to be near from the opposite goal; and (iii) to shoot at goal with the lowest level of opposition. In almost all the tasks, the size of the field was reduced to $1 / 2$ of the basketball court and the number of players was also reduced to 3-4 player per team. To further illustrate the lessons contents, Table 2 presents an example, specifically lesson 8 in which were represented all the tactical principles of play. In addition, it was developed questioning, as a cognitive tool (Vickers, 2007). In this sense in each task it was prepared some questions. The teacher asked to the group the questions after seven minutes of practice. After one minute asking some question, students returned to played in the same task (Pizarro, Práxedes, Travassos, Del Villar \& Moreno 2019). Additionally, the teacher asked individualized questions to those players who did not solve the task.
Table 2

Example of the lesson 8 of theTGfU unit (SSGs + questioning).

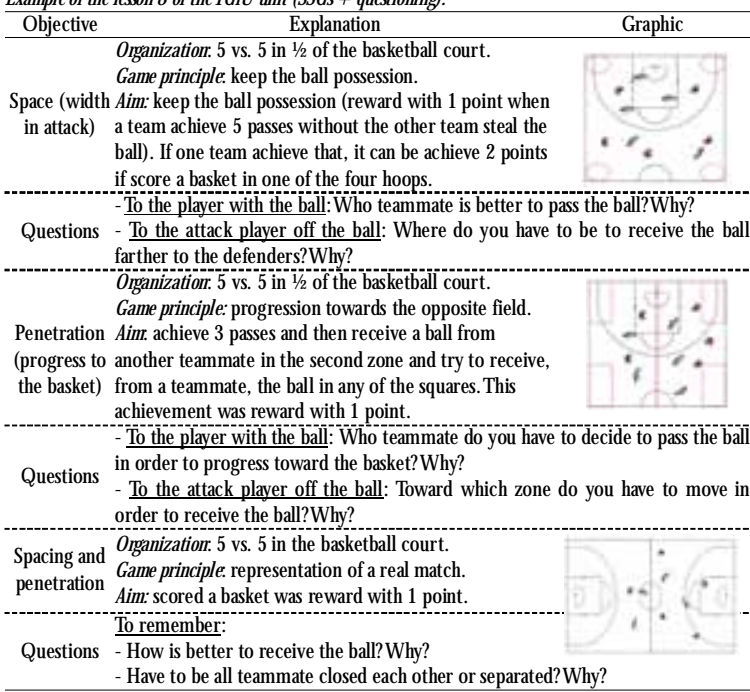

Intervention program based on unstructured practice. This program was conducted in the school recess, in the same days in which the unit was being developed. 0 nly the experimental group participated in this program. Specifically, participants played one small-sided game with a length of $8^{\prime}$ per day. In the first two weeks (4 sessions) they play 2 vs. 2 , and in the last two weeks (4 sessions), 4 vs. 4. It was a like a competition league in which each team played with the others. Participants organised their teams with the following rule: each team must have girls and boys. Regarding to the teacher, he didn't say any correction or feedback, he was there in case it was any problem. Players played with the rules that they were learning (i.e. not hitting or charging, not dribbling the ball with both hands at the same time, taking more than 3 steps without dribbling the ball, and once the attacker team has brought the ball across the mid-court line they cannot go back across the line). It was not necessary the presence of a teacher to a be a referee.

\section{Dependent variables}

Decision-making and execution of the passing action were measured in the pre-test and post-test. Decisionmaking is defined as the process whereby learners select one type of game action from a series of alternatives to execute it at a specific moment and in a real game situation (Bar-Eli, Plessner \& Raab, 2011). It was measured by the percentage of successful decision over thetotal number of decisionsmade. Execution is defined as the performance, outcome, or the final result of the motor execution (Bar-Eli et al., 2011). It was also measured by the percentage of successful execution over the total number of execution made. 


\section{D ata collection}

In pre-test and post-test phases, students participated in a small-sided game (3 vs. 3) with a length of 10', divided in two parts of $5^{\prime}$ with a recovery of 1 The size was $20 \times 12$ meters (length $x$ width). In both phases (pre-test and post-test, the teams were the same (i.e. participants played against the same classmates). Also, the teams that faced each other were composed by students with the same level of expertise. The main rules were the following: not hitting or charging, not dribbling the ball with both hands at the same time, taking more than 3 steps without dribbling the ball, and once the attacker team has brought the ball across the mid-court line they cannot go back across the line. There were not free throws, after a foul commit by one team, another team started a new play from the nearest place of the one bound. Moreover, the PE teacher had an extra ball to give participants if the ball goes far away, to avoid lose time, and was the referee, to guarantee the compliance of the rules.

The decision-making and execution assessment was based on indirect and external systematic observation, a methodology that had been used in previous studies to measure learners' decision-making and execution in real gamesituations in $P E$, which representstheinfluence of the environment on decision-making and execution (Travassos, et al., 2013). The Game Performance Evaluation Tool (GPET) observation instrument (Garrcía-López, González-Víllora, Gutiérrez \& Serra, 2013), was used to assess the decision-making and execution of the pass action. This instrument permitted evaluating the player's tactical problem-solving skills, by means of selecting and applying an appropriate technique, and eval uating both measurements (decisionmaking and execution) in real game situations, as it has had in previousstudies (Gonzál ez-Espinosa, et al. , 2017; Práxedes, et al., 2019).

Through thisinstrument, decision-making wascoded as 1 , if successful (e.g. passing to a teammate who is unmarked) or 0 if unsuccessful (passing to a player who is marked closely or there is a defensive player in a position to cut off the pass; passing to an area of the pitch where no team-mate is positioned). Likewise, execution was coded as 1 , if successful (passing to a teammate: to his body if he is stationary, lead pass if he is running) or 0 if unsuccessful (the pass is too high, too far, behind or out of play).

Decision-making variable was assessed by means of the percentage of succesfful decisions referring to the student's capacity to take appropriate decisions under specific conditions. Likewise, execution was assessed by means of the percentage of succesfful actions completed by students. To calculate the percentage of successful decisions and executions, the total number of decisions and executions were divided by the sum of the successful and unsuccessful decisions, and executions, and multiplied by 100 (M itchell, 0 slin, \& Griffin, 2006).

A research observer was trained to analyze decisionmaking and the execution of passing action. Thisobserver was trained by an expert in basketball (Level 1 by the Spanish Basketball Federation and Degree in Sport and Exercise Sciences), who has five years of experience in observational methodology (researcher with experience in research projects). The observer had to undergo a training process with an expert researcher, establishing a total of five 45-minute sessions in order to obtain suitable reliability in both variables.

As a preliminary step, the expert met with the observer to clarify possible doubts about the observation instrument and the coding criteria of each dependent variable (decision-making and execution). Subsequently, the observations were carried out with a sample of more than $10 \%$ of the total (Tabachnick \& Fidell, 2007). Interobserver reliability was calculated using the following formula: agreements/ (agreements + disagreements) $x 100$ measure. 0 nce this value was calculated, the Cohen kappa index was used. All training values were observed to be above .90, surpassing the value .81 from which an adequate agreement is considered (Fleiss, Levi \& Cho Paik, 2003), thus achieving the necessary reliability for the subsequent coding of the dependent variables. To guarantee the time reliability of the measurement, as it was developed in other studies (Pizarro, et al., 2019; Práxedes, et al., 2019) the same sample of matches was analyzed with a time difference of ten days, obtaining intraobserver reliability results of .91. These results reflected very good concordance, thus obtaining the necessary reliability for the subsequent coding of the dependent variable.

\section{Procedures}

In order to guarantee the correct application of the intervention program, the PE teacher was instructed by an expert. The expert was a professor in Sport and Exercise Sciences and has 12 years' experience in teaching methodologies in both contexts, educational and coaching. As in the previous studies (Gil-Arias, Harvey, Cárceles, Práxedes, \& DelVillar, 2017; Harvey, et al. , 2010; Práxedes, et al. , 2019), the training program to instruct the teacher was developed over three weeks 
before the intervention program was applied. In the first week, the teacher was required to read threeTGfU model-related articles (Gil-Arias et al. , 2017; Práxedes, García-González, Moreno-Cortés, M oreno \& M oreno, 2016b; Tan, et al., 2012). For each article, the teacher met with the first author to discuss the contents. In the second week, the teacher designed learning tasks based on the principles ofTGfU focusing on the application of small-sided games and questioning. Finally, in the third week a practical application of the tasks took place with a group of the same year of Secondary Education. In total, the PE teacher dedicated 5 hours per week. In this sense, it was assessed the intervention using the checklist developed to the structured practice (seeTable 4).

O nce the teacher training process was completed, pre-test data were obtained. After that, the intervention began, which was conducted over a period of four weeks. The experimental group experienced aT GfU basketball unit combined with a program based on unstructured practice, while the control group experienced only the TGfU basketball unit. Finally, and when the intervention phase was completed, the post-test data were obtained.

\section{Instructional and Treatment Validity}

To assess the fidelity of the intervention, a checklist was used for each practice (structured practice based on TGfU model and unstructured practice) (Hastie \& Casey, 2014). To create both checklist, it has been followed the example of Gil-Arias, Claver, Práxedes, del Villar \& Harvey (2020). Then, authors followed the scientist literature to identified the more relevant items for each intervention. In Table 3 are represented the items related toT GfU model and inTable 4, items which enabled researchers to measure the fidelity to unstructured practice. The fidelity assessment was based on direct and external systematic observation. The first

Table 3.

Instructional Checklist of structured practice (TGfU during PE sessions.

Date:

1. All the tasks are related to small-sided games.

2. All the tasks have different solutions.

3. The teacher simply explains the task without providing solutions

4. The number of players per team is between 2 and 5 .

5. The pitch is reduced proportionally to the number of players

6 . The time to maintain the ball possession without doing an action is not

limited for any task.

7. The teacher observed each student and used the questioning to provoke the

reflection.

8. Each group receives at least one question.

Table 4.

Instructional Checklist of unstructured practice (during school recess).

Date:

1. In the first two weeks, students play 2 vs. 2, and in the last two weeks, 4 vs. 4.

2. The teacher supervises the practice without intervention or any feedback

3. Students organize their teams with the rule "each team has girls and boys".

4. Students are independent (e.g they knows the rules, it is not necessary the

presence of a teacher to a be a referee). author and one additional observer (researcher with 15 years' experience supervising teaching methodologies) observed a sample of two lessons for each group, more than $10 \%$ the total sample (Tabachnick \& Fidell, 2007). A $100 \%$ agreement was reached between the two observers, who confirmed that all key aspects included in the checklist with regard to the features of theTGfU model and to the unstructured practice were used in each observed-session.

\section{Statiscal analysis}

The statistical program SPSS v21.0 (Chicago, IL) was used for the data analysis and processing. Data normality was examined through the KolmogorovSmirnov test (for samples of more than 30 subjects), indicated data did not follow a normal distribution ( $p<$ .05), which led to the use of non-parametric statistics. In addition, as a prior stage to the application of the intervention program, the homogeneity of variance through Levene's test was developed, determining that the groups were equivalent in all study variables (decision-making, Levene statistic $=.505, p=483$; execution, Levene statistic $=.704, p=408$ ).

Secondly, intergroup analysisthrough $M$ ann-W hitney test for independent measures, was developed to compare the mean scores of each measure between both groups in each dependent variable. Finally, and in order to verify any differences between the different times in each dependent variable, it was developed W ilcoxon test for measures related to Bonferroni correction (significance level of .05/2=.025). For the MannW hitney andW ilcoxon tests, effect sizes were calculated using the following equation $\mathbf{r}=\mathbf{Z}$ / 》 $\mathbf{N}$ (Rosenthal \& DiMatteo, 2001). The eûect size (ES) was classiûed as no eûect (ES < 0.04), minimum eûect $(0.04<\mathrm{ES}<$ $0.25)$, moderate eûect $(0.25<E S<0.64)$, and strong eûect (ES > 0.64) (Ferguson, 2009).

\section{Results}

Results according to each measure (intergroup analysis) are presented below in Table 5 . W ith respect to the pre-test, no significant differences were obtained between both group in any of the variables (decisionmaking and execution). Regarding to the post-test, it can be seen the same results that in the pre-test.

Results according to the group (intragroup analysis) are presented below in Table 6 . W ith respect to the experimental group, significantly higher values were 
obtained in post-test with respect to pre-test, in the decision-making and execution of the passing action. Moreover, the effect size of the decision-making is greater than the execution. W ith respect to the control group, significantly higher values were obtained in posttest with respect to pre-test, in the decision-making of the passing but not in the execution of this action.

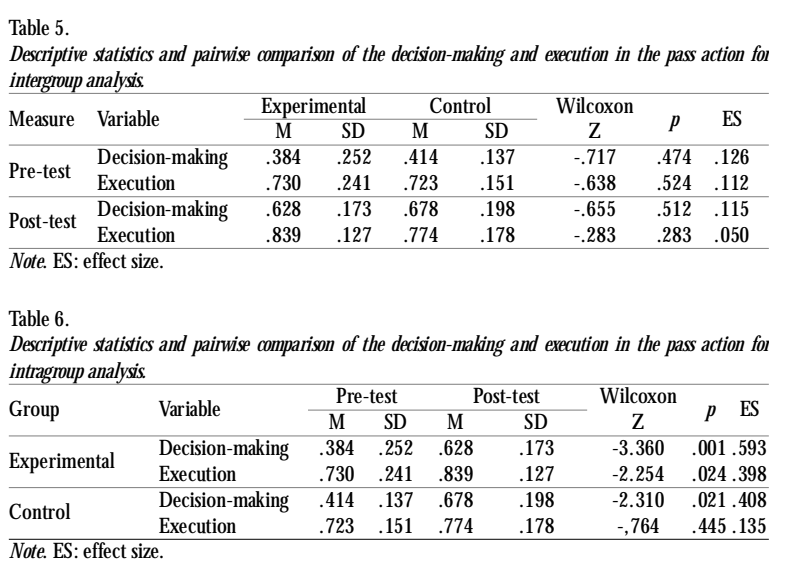

\section{Discussion}

The purpose of this study was to analyze the effect of a unit of basketball (structured practice) based on the TGfU model (developed in PE lessons) combined with a program based on unstructured practice (developed in school recess), in comparison to the only application of the unit, on the decision-making and execution of the pass action in PE students. In this regard, the experimental group participated in both programs (structured practice and unstructured practice) while the control group participated only in the structured practice.

In terms of the decision-making, results show no significant differences between both groups(experimental and control) in the post-test. However, and regarding the intragroup analysis, results show significantly higher values in the post-test, in comparison with the pre-test, in both groups. In thissense, learnersfrom control group, who participated only in the structured practice (unit based on TGfU model), also improved the decisionmaking of the pass action. Thus, these findings seem to indicate that the basketball unit based on TGfU was effective to improve the decision-making of all the PE students.

There are a number of possible reasons for these outcomes. Firstly, the representativeness of the practice (provided with the task design based on the principles of the game) could have led to learners to make intelligent decisions based on their own, teammates' and opponent' action capabilities (Fajen, et al., 2009).
Additionally, the unit was designed based on the tactical contents present in the game, exposing learners to contextualized situations that occur normally in the game as required by TGfU (Calábria, Greco \& Pérez-Mora les, 2019; Gutiérrez, Fisette, García López \& Contreras, 2014). In this way, make decisions in terms of decide to pass the ball or when is the best moment to do this action, have led to learners a better adaptation to the competitive environments. Secondly, through the principle of exaggeration, the teacher could emphasize specific tactical learning objectives (provided with the modification of the game's rules) that guide players towards the task goals and to explore new solutions for the play (Passos, et al., 2008). For example, the rule «receive a ball from another teammate in a free zone to achieve one point» could guide the attention to occupy the free spaces. And finally, the modification of the tactical complexity permitted adapt task to students needs and level of competence (Práxedes, et al. , 2019). As Pizarro et al. (2019) indicated, thenumerical superiority in attack increases the number of passing possibilities of attacking team to maintain ball possession or to progress on the ûeld. In this regard, modify the task complexity seems to be a good strategy to highlight passing lines and to guide players to explore information that sustain their passing decisions and actions. Therefore, the task design based on the pedagogical principles seems to be effective to developed decision making and skill execution (Tan, et al., 2012).

On the other hand, the application of questioning, as a methodological tool, has probably had a decisive influence on the results obtained, favouring cognitive development (Gréhaigne, Richard \& Griffin, 2005) and consequently improving the decision-making (García González, et al., 2014; Práxedes, et al., 2016a). In line with our results, Gaspar, Del Villar, Práxedes, M oreno (2019) obtained that the students who received the questioning when developing SSG improved their decision-making compared to those who did not.

In terms of the execution, results show no significant differences between both groups in the post-test. However, and regarding the intragroup analysis, results show significantly higher values in post-test in the experimental group. These findings seem to indicate that the extra time, promoted by the unstructured practice in the school recess, led a significantly improvement of this variable. $\mathrm{On}$ the contrary, learners who were not exposed to the unstructured practice, did not improved theexecution of the passaction. In the scientific literature, ûndings of some previous research are aligned with the 
results obtained in our study. In this regard, in a study developed in an educational context, in which it was analyse the effect of a teaching program based onTGfU model, results showed significant differences in the decision-making but not in the execution (Práxedes, et al., 2016b). These findings indicated that the length of the program must be extensive to improve this varia ble, as determined by previous studies that indicated the need for programs to include more than 12 sessions (Harvey, et al. , 2010; Turner \& Martinek, 1999). In this regard, it seems that we should increase the length of the units to provoke improvements in the execution. However, in the educational context there is a limitation in the number of hours dedicated to the PE subject (specifically, two weekly sessions of 55-minutes). As some systematic reviews have suggested, school recess could make a meaningful contribution to physical activity of children and adolescents (Ridgers, et al., 2012; Parrish, et al., 2013). In this sense, combine structured and unstructured practice could be a solution to achieve the skills acquisition (Coutinho, et al ., 2016).

The current study had several strengths. First, instruments with sound reliability and validity were utilized to collect the data (i.e. GPET instrument). Second, another strength could be the fidelity of the intervention (the PE lessons were supervised by a researcher using a 8-item checklist and the teacher was instructed by an expert such as in previous research Práxedes, et al., 2019; Gil-A rias, et al., 2017). And third, the novelty of this study, there are no research that have sought to investigate the effects of intervention programs that combine the structured practice and the unstructured practice on the decision-making and execution variables. Despite the aforementioned strengths, the study results should be treated with some caution due to the utilization of a small sample and only one teacher, which limits the capacity to extrapolate the results. In future studies, we recommend to instruct more teachers in order to increase the number of $P E$ classes and ûnally, the participants. On other hand, it would be interesting a third group that participate only in the school recess, which would provide more power to detect significant differences.

\section{Conclusions and practical implications}

In the educational context, specifically in Spain, in which children have two weekly 55-minutes PE lessons, findings suggest the promotion of unstructured practices in order to increase the amount of time of play.
Developing this practices during the school recess could be a good strategy. It seems that with this extra time, learners will improve both the decision-making and the execution variables. Considering the potential contribution of unstructured practices for students, teachers should reflect on encouraging and creating more opportunities for such experiences (e.g enhance the school facilities during free time to encourage students play with specific material such as balls or baskets with less height).

W ithin the structured practice, TGfU model is considered effective to improve the decision-making. SSGs allow contextualized practices in which learners are the centre of the learning and then they really transfer tactical knowledge among those games to the real competition. Thus, teachers should considerer it as a methodology in their PE lessons. Furthermore, we highlight the use of questioning to favour cognitive development and thus the decision-making.

\section{References}

Araújo, D., \& Davids, K. (2011). Talent development: from possessing gifts, to functional environmental interactions. Talent Development \& Executioncellence, 3, 23-26.

Bar-Eli, M., Plessner, H., \& Raab M. (2011). Judgement, decisionmaking and success in sport. West Sussex: W iley-Blackwell.

Bayer, C. (1992). La enseñanza de los juegos deportivos colectivos. Barcelona: Hispano Europea.

Bunker, D., \& Thorpe, R. (1982). A model for the teaching of games in secondary schools. Bulletin of Physical Education, 18, 5-8.

Calábria, M., Greco, P.)., \& Pérez-M orales, J. C. (2019). Teaching Games for Understanding in basketball camp: the impact on process and product performance. RICYDE. Revista Internacional deCienciasdel Deporte, 15(56), 209-224. https: / / doi.org/ $10.5232 /$ ricyde2019.05606

Côté, . . \& Erickson, K. (2015). Diversiûcation and deliberteplay during the sampling years. In J. Baker, \& D. Farrow (Eds.), Routledge handbook of sport expertise (pp. 305-316). London: Routledge.

Côté, J., Baker, J., \&A Abernethy, B. (2003). From play to practice: a developmental framework for the acquistion of expertise in team sports. In J. L. Starkes and K. A. Ericsson (Eds.), Expert Performance in Sports: Advances in Research on Sport Expertise (pp. 8995). Champaign, IL: Human Kinetics.

Côté, J., Baker, J., \&A bernethy, B. (2007). Practiceand play in the development of sport expertise. In G. Tenenbaum and R. C. Eklund (Eds.), Handbook of Sport Psychology (pp. 184-202). NewYork, EEUU: JohnW iley \& Sons Inc.

Cote, J., Erickson, K., \&A Abernethy, B. (2013). Play and practice during childhood. In J. Cote, $\&$ R. Lidor (Eds), Conditions of children's talent development in sport (pp. 9-20). M organtown, 
WV:FIT.

Coutinho, P., M esquita, I., Davids, K., Fonseca, A. M., \& Côté, J. (2016). How structured and unstructured sport activities aid the development of expertise in volleyball players. Psychology of Sport \& Exercise, 25, 51-59.

Creswell, J.W. (2014). Research Design: Qualitative, Quantitative and Mixed Methods Approaches (4thed.). Thousand O aks, CA: Sage.

Davids, K., Araújo, D., Correia, V., \&Vilar, L. (2013). How smallsided and conditioned gamesenhanceacquisition of movement and decision-making skills. Exercise and Sport Sciences Reviews, 41(3), 154-161. https:// doi. org/ 10.1097/ JES. 0b013e318292f3ec

Davids, K., Güllich, A., Shuttleworth, R., \& Araújo, D. (2016). Understanding environmental and task constraints on talent development. Analysis of micro-structure of practice and macro-structureof developmenthistories InJ. Baker, S. Cobley, J. Schorer, \& N Wattie (Eds.), Routledge Handbook of Talent Identification and Development in Sport. New York, EEUU: Routledge.

Fajen, B. R, Riley, M. A, \& Turvey, M. T. (2009). Information, affordances, and the control of action in sport. International Journal of Sport Psychology, 40, 79-107.

Ford, P. R. \&W illiams,A. M . (2012).Thedevelopmental activities engaged in by elite youth soccer players who progressed to professional status compared to those who did not. Psychology of Sport and Exercise, 13, 349- 352.

Fleiss, J. L., Levi, B., \& Cho Paik, M. (2003). Statistical methods for ratesand proportions. 3th edition. NewYork, EEUU:W iley.

Ferguson, C. J. (2009). An eûect size primer: a guide for clinicians and researchers. Professional Psychology: Research and Practice, 40, 532-538. https: / / doi.org/ 10.1037/ 20015808

García-López, L. M., González-Víllora, S. , Gutiérrez, D. \& Serra, J. (2013). Development and validation of the Game PerformanceEvaluationTool (GPET) in soccer. Revista Euroamericana deCiencias $D$ el Deporte, 2, 89-99.

García-González, L., M oreno,A., Gil-Arias, A., M oreno, M. P., \& DelVillar, F. (2014). Effects of decision training on decisionmaking and performance in young tennis players: An applied research. Journal of Applied Sport Psychology, 26(4), 426-440. https: / / doi.org/ 10.1080/ 10413200.2014.917441

Gaspar,V. M., DelVillar, F., Práxedes, A., \& M oreno,A. (2019). El cuestionamiento como herramienta fundamental para el de sarrollo de la toma de decisiones de los alumnus en Educa ción Física. Movimento, 25, e25028. https:/ / doi.org/ $10.22456 / 1982-8918.86547$

Gil, A., \& del Villar, F. (2014). Aplicación de un programa de entrenamiento decisional, en tiempo real de juego, para la mejoraderendimiento táctico individual del deportista. EnL. García-González and F. Del-Villar (Eds), Entrenamiento táctico y decisional en el deporte (pp. 132-146). Madrid: Síntesis.

Gil-Arias, A., Claver, F., Práxedes, A., delVillar, F., \& Harvey, S. (2020). Autonomy, motivational climate, enjoyment and competence in physical education: Effect of a hybridTGfU/ SE unit. European Physical Education Review, 26 (1),36-53. https:/
/ doi.org/ 10.1177/ 1356336X18816997

Gil-Arias,A., Harvey, S., Cárceles,A., Práxedes, A., \& DelVillar, F. (2017). Impact of a hybrid TGfU-Sport Education unit on student motivation in physical education. PlOS ONE, 12 (6), e0179876.

https:/ / doi.org/ 10.1371/ journal. pone. 0179876

González-Espinosa, S., Feu, S., García Rubio, J., Antúnez, A., \& García-Santos, D. (2017). Diferencias en el aprendizaje según el método de enseñanza-aprendizaje en el baloncesto [Differences in learning according to the teaching method in basketball]. Journal of Sport Psychology, 26(1), 65-70.

Gréhaigne, J. F., Richard,J., \& Griffin, L. (2005). Teaching and learning team sports and games. New York: Routledge.

Gutiérrez, D., Fisette, J., GarcíaLópez, L. M. \& Contreras, 0. (2014). Assessment of secondary school students' game gerformance related to tactical contexts. Journal of Human Kinetics, 42, 223-234. http:// www.johk. pl/ files/ 37gutierrez.pdf

Harvey, S., Cushion, C. J., Wegis, H. M , \& Massa-González, A. N. (2010). Teaching games for understanding in American highschool soccer: a quantitative dataanalysis using the game performance assessment instrument. Physical Education and Sport Pedagogy, 15(1), 37-41. https:/ / doi.org/ 10.1080/ 17408980902729354

Harvey, S., Gil-AriasA., Smith, M. L., \& Smith, L. R. (2017). Middle and elementary school students' changes in selfdetermined motivation in a basketball bnit baught using the Tactical Games model. Journal of Human Kinetics, 59, 39-53. http:/ / www. johk. pl/ files/ 10078-59-2017-v59-201705.pdf

Harvey, S. \& Jarrett, K. (2014). Review of the game-centred approaches to teaching and coaching literature since 2006. Physical Education and Sport Pedagogy, 19(3). https: / / doi.org/ 10.1080/ 17408989.2012.754005

Hastie, P. A., \& Casey, A. (2014) Fidelity in models-based practice research in sport pedagogy: A Guidefor future investigations. Journal ofTeaching in Physical Education, 33(3), 422-431. https:/ / doi.org/ 10.1123/ jtpe. 2013-0141

Kirk, D. , \& M acPhail, A. (2002).Teaching gamefor understanding and situated learning: rethinking the Bunker-Thorpe M odel. Journal of Teaching in Physical Education 21(2), 177- 192. https:/ / doi.org/ 10.1123/ jtpe. 21.2.177

Kirk, D. (2013). Educational value and models-based practice in physical education. Educational Philosophy andTheory,45(9), 973986.

Lex, H., Essing, K., Knoblauch, A., \& Schack, T. (2015). Cognitive representations and cog- nitive processing of team-specific tacticsin soccer. PLOSON E 10(2) :e0118219 https:/ / doi.org/ 10.1371/ journal. pone. 0118219

Machado, J. C., Barreira, D., Galatti, L., Chow, J.Y., Garganta, J. \& Scaglia,A.J. (2018): Enhancing learning in the context of street football: a case for Nonlinear Pedagogy. Physical Education and Sport Pedagogy, 24(2). https:// doi.org/ 10.1080/ 17408989.2018 .1552674 
Mandigo, J., Lodewyk, K., \& Tredway, J. (2019). Examining the impact of aTeaching Games for Understanding approach on the development of physical literacy using the passport for life assessment tool. Journal of Teaching in Physical Education, 38(2), 136-145. doi: 10.1123/ jtpe.2018-0028 https:/ / doi.org/ 10.1123/ jtpe. 2018-0028

Metzler, M. W. (2011). Instructional Models for Physical Education (3rd ed.). Scottsdale, AZ: Holcomb Hathaway.

Mitchell, S. , O sin, J., \& G riffin L. (2006). Teaching sportconceptsand skills. a tactical gamesapproach. Champaign, IL: Human Kinetics.

Morales-Belando, M. T., \&A rias-Estero, J. L. (2019). Adaptación práctica del enfoqueTeaching Games for U nderstanding para la enseñanza de la vela en iniciación (A practical proposal of Teaching Games for Understanding in sailing initiation). Retos, 37(37), 738-741. https:/ / doi. org/ $10.47197 /$ retos. v37i37.72788

Morales-Belando, M.T., Calderón,A., \&Arias-Estero, J. L. (2018). Improvement in game performance and adherence atter an aligned TGfU floorball unit in physical education. Physical Education \& Sport Pedagogy, 23(6), 657-671. https: / / doi.org/ $10.1080 / 17408989.2018 .1530747$

Passos, P., Araújo, D., Davids, K., \& Shuttleworth, R. (2008). Manipulating constraints to train decision making in rugby union. International Journal of Sports Sciences and Coaching, 3, 125- 140 . https:/ / doi. org/ 10.1260/ 174795408784089432

Parrish,A. M., O kely,A. D., Stanley, R. M., \& Ridgers, N. D. (2013). Theeffect of school recessinterventionson physical activity: a systematic review. Sports Medicine, 43, 287-299. https:/ / doi.org/ 10.1007/ s40279-013-0024-2

Phillips, E., Davids, K., Renshav, I. \& Portus, M. (2010). Expert performancein sportand the dynamics of talent development. Sports Medicine, 40, 271-283.

Pizarro, D., Práxedes, A.,Travassos, B., DelVillar, F., \& M oreno,A. (2019). The effects of a nonlinear pedagogy training program in the technical-tactical behaviour of youth futsal players. International Journal of Sport Science \& Coaching, 14(1), 15-23. https:/ / doi.org/ 10.1177/ 1747954118812072

Práxedes,A., DelVillar, F., M oreno,A., Gil-Arias,A. \& \& Davids, K. (2019). Effects of a nonlinear pedagogy intervention programme on the emergent tactical behaviours of youth footballers. Physical Education and Sport Pedagogy, 24(4), 332343. https:/ / doi.org/ 10.1080/ 17408989.2019.1580689

Práxedes, A., García-González, L., Moreno-Cortés, A., Moreno, M. P., \& M oreno, A. (2016a). Aplicación de un programa de intervención parala mejora de la comprensión tácticaen fútbol sala. Un estudio en contexto educativo. M ovimento, 22(1), 51-62.

Práxedes, A., M oreno, A. Sevil, J., GarcíaGonzález, L., \& Del Villar, F. (2016b). A preliminary study of the effects of a comprehensive teaching program, based on questioning, to improvetactical actionsin young football lers. Perceptual \& M otor Skills, 122 (3), 742-756. https:/ / doi. org/ 10.1177/ 0031512516649716
Renshaw, I. J., Chow, Y., Davids, K., \& Hammond, J. (2010). A constraints-led perspective to understanding skill acquisition and gameplay:A basisfor integration of motor learningtheory and physical education praxis? Physical Education and Sport Pedagogy, 15(2), 117-137. https:/ / doi.org/ 10.1080/ 17408980902791586

Ridgers, N. D., Salmon, J. , Parrish, A. M., Stanley, R. M ., \& O kely, A. D. (2012). Physical activity duringschool recess: asystematic review. American Journal of Preventive Medicine, 43(3), 320-328. https:/ / doi.org/ 10.1016/ j.amepre.2012.05.019

Rodríguez-Fernández, J., Pereira, V., Pereira, B., \& Condessa, I. (2019). Análisis de lainteracción entre pares en los recreos de $1^{0}$ ciclo de enseñanza básica en Portugal (Analysis of peer interaction during recess in 1st cycle of basic education in Portugal). Retos, 36(36), 97-102. https:/ / doi. org/ $10.47197 /$ retos. v36i36.68566

Rosenthal, R., \& DiM atteo, M. R. (2001). Meta-Analysis. Recent developments in quantitative methods for literature reviews Annual Review of Psychology, 52 (1), 59-82. https:/ / doi.org/ 10.1146/ annurev. psych. 52.1.59

Sampaio, J. E., Lago, C., Gonçalves, B., M açãs, V. M., \& Leite, N. (2014). Effects of pacing, statusand unbalancein timemotion variables, heart rate and tactical behaviour when playing 5-a side football small-sided games. Journal of Sciencesand M edicine in Sport, 17, 229-233. https:// doi.org/ 10.1016/ j.jsams. 2013.04.005

Tabachnick, B. G. \& \& Fidell, L. S. (2007). U ing multivariatestatistics. Boston, MA: Allyn and Bacon.

Tan, C., Chow, J.Y., \& Davids, K. (2012). «H ow doesT GfU work?»: examining the relationship between learning design inTGfU and a nonlinear pedagogy. Physical Education \& Sport Pedagogy 17(4), 331-348. https:// doi. org/ 10.1080/ 17408989.2011 .582486

Travassos, B., Araújo, D., Davids, K., O'Hara, K., Leitão, J., \& Cortinhas, A. (2013). Expertise effects on decision- making in sport are constrained by requisite response behaviours- $A$ metazanalysis. Psychology of Sport and Exercise, 14(2), 211-219. https:/ / doi.org/ 10.1016/ j.psychsport.2012.11.002

Turner,A., \& Martinek, T.J. (1999). An investigation intoTeaching Games for Understanding: Effects on skill, knowledge and game play. Research Quarterly for Exercise and Sport, 70(3), 286296.

Ú bedaCColomer, J., Monforte, J., \& Devís Devís, J. (2016). Percepción del alumnado sobre una U nidad Didáctica de enseñanza comprensiva de los juegos deportivos de invasión en Educación Física. Retos, (31), 306-311. https:/ / doi.org/ 10.47197/ retos. v0i31.53507

Vickers, J. N. (2007). Perception, cognition, and decision training. The quiet eyein action. Champaign, IL: Human Kinetics.

Webb, P. I., \& Pearson, P.J. (2008). An integrated approach to Teaching Gamesfor Understanding (TGfU). En 1stAsia Pacific Sport in Education Conference (pp. 1-11). Adelaide. 